\title{
Üniversite Öğrencilerinde Somatik Belirtiler, Bağlanma Stilleri ve Suçluluk Utanç Duyguları Arasındaki İlişkinin İncelenmesi *
}

\section{Analysis of The Relationship Between Somatic Symptoms, Attachment Styles and Feelings of Guilt Shame in University Students}

Gizem Gerdan, ${ }^{\text {a, }}$ Murat Kurt ${ }^{\text {b }}$

a Arş. Gör. Ondokuz Mayıs Üniversitesi, Fen Edebiyat Fakültesi, Psikoloji Bölümü, 55270, Samsun/Türkiye ORCID: 0000-0001-6066-7059

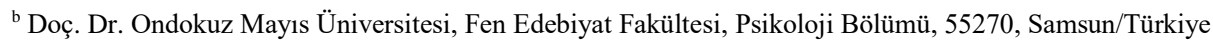
ORCID: 0000-0001-8206-606X

\section{MAKALE BİLGİSI}

\section{Makale Geçmişi:}

Başvuru tarihi: 23 Eylül 2019

Düzeltme tarihi: 28 Kasım 2019

Kabul tarihi: 18 Aralık 2019

\section{Anahtar Kelimeler:}

Somatik Belirtiler

Bağlanma

Suçluluk

Utanç
ÖZ

Çalışmanın amacı suçluluk, utanç ve bağlanma stillerinin somatizasyonu yordama derecesi ve aralarındaki ilişkiyi; internette sağlığa yönelik araştırma yapma sıklığının, somatizasyon ve bağlanma stili puanları üzerindeki etkisini incelemektir. Çalışmanın verileri 204 üniversite öğrencisinden toplanmıştır. Katılımcılara Suçluluk Utanç Ölçeği, İlişki Ölçekleri Anketi ve Belirti Tarama Listesi'nin somatizasyon alt ölçeği uygulanmıștır. Analizler sonucunda somatizasyon, bağlanma stilleri ve suçluluk-utanç puanları arasında anlamlı ilişki bulunmuştur. Bağlanma stilleri ve utanç puanları somatizasyonu \%36 düzeyinde yordamaktadır. Cinsiyete göre ve internette sağlığa ilişkin araştırma yapma sıklığına göre puanlar farklılaşmıştır. Güvenli bağlanan bireylerin somatik belirtiler gösterme olasılığı daha düşüktür.

\section{A RTICLE INFO}

\section{Article history:}

Received 23 September 2019

Received in revised form 28 November 2019

Accepted 18 December 2019

Keywords:
Somatic Symptoms
Attachment
Guilt
Shame

\begin{abstract}
A B S T R A C T
The aim of this study was to determine to what extent guilt, shame and attachment styles predict somatization, to find out the relationship between these and to examine the frequency of making health-related research on the internet on somatization and attachment style scores. The data were collected from 204 university students. The participants were applied Guilt Shame Scale, Relationship Scales Questionnaire and somatization subscale of Symptom Check List. As a result of the analyses, a significant relationship was found between somatization, attachment styles and guilt-shame scores. Attachment styles and shame scores predict somatization at a rate of $36 \%$. Scores differed according to gender and the frequency of making health-related research on the Internet. Individuals with secure attachment are less likely to show somatic symptoms.
\end{abstract}

\section{Giriş}

Somatizasyon, çözülememiş ruhsal sıkıntıların bedensel belirtilerle ifade edilmesi olarak tanımlanmaktadır (Lipowski, 1988). Biyopsikososyal bir varlık olan birey psikososyal ya da duygusal sorunlarını bedensel olarak ifade edip tıbbi yardım arayışına girmektedir (Ford, 1986).
Sağlık kuruluşlarına belirli fiziksel belirtilerle başvuran kişilerde $\% 30-\% 60$ oranında semptomlarıyla ilișkili tıbbi bir dayanak bulunamamaktadır (Kirmayer ve Robbins, 1991). $\mathrm{Bu}$ kişilerin sık sık hastaneye başvurdukları, çok sık ilaç kullandığı ve yaşam kalitesinin de düşük olduğu bilinmektedir (Noyes, Longley, Langbehn, Stuart ve Kukoyi, 2010). Siklıkla yapılan konsültasyonlara rağmen

\footnotetext{
* Sorumlu yazar/Corresponding author.:

e-posta: gizemgerdan@gmail.com
} 
tanılanmasında güçlük çekilen, açıklanamayan bedensel belirtilere sahip bu kişiler pek çok uzmana başvurmaktadır. Açıklanamayan şikayetleri ile ilişkili olarak mesleki ve sosyal işlevsellikte ciddi sıkıntılar yaşamakta ve uzun vadede medikal, sosyal ve ekonomik bedeller ödemektedir (Stuart ve Noyes, 1999). Somatizasyona sahip kişilerde olumsuz yaşam deneyimlerinin ve erken dönem yaşantılarının önemli olduğu ifade edilmektedir (Ciechanowski, Walker, Katon ve Russo, 2002). Bowlby (1969:15) erken dönemde ilişkisel deneyimlerle şekillenen bağlanma stillerinin, yetişkinlikte bireylerin ruh sağlıklarını etkileyebileceğini öne sürmektedir. Nitekim somatik belirtiler ile bağlanma stilleri arasında anlamlı bir ilişki bulunmaktadır (Ciechanowski vd., 2002).

Çocuk ilk bakım veren kişi ile genellikle anneyle yakın ve duygusal ilişki kurmaktadır. Erken dönemde bu yakın ilişkide var olan ilişkisel deneyimler, bireyin kendisi ve diğerleri ile ilgili temsiller oluşturmasını sağlar. Temsilin içeriği ile ilişkili olarak birey korku duyduğu ya da tehlike hissettiği ve görece stresli olduğu durumlarda dayanıklı ve tutarlı olan bu bağdan destek alarak baş etmektedir (Ainsworth, 1979). Bir diğer anlatımla, bağlanmayla ilişkili bu temsiller kişinin stresle ya da kaygıyla baş etme becerisinde rol oynamaktadır. Bartholomew ve Horowitz (1991) literatürde de sıklıkla anılan dört çeşit bağlanma stili tanımlamaktadır: Güvenli, korkulu, saplantılı ve kayıtsız. Güvenli bağlanmada kişi olumlu benlik algısına sahip olmakla birlikte kendini sevilmeye değer görür ve diğer insanları da kabul edici, duyarlı olarak algılamakta ve işlevsel olmayan kaygılara girmemektedir. Saplantılı bağlanmada birey, olumsuz benlik algısı ve yoğun değersizlik içinde olup diğerleri tarafından kabul görmek ve onay almak için çabalamaktadır. Korkulu bağlanmada reddedilme korkusu ile birey yakın ilişkilerden kaçınmaktadır ve güvensizlik duygusu içerisindedir. Kayıtsız bağlanmada bireyler kendilerine ilişkin olumlu benlik imgesine, diğerlerine ilişkin ise olumsuz imgelere sahiptir.

Suçluluk ve utanç duyguları da erken dönem yaşantıları ile ilişkili duygulardır (Lopez vd., 1997). Her iki duygu ebeveynlerle kurulan ilk temastan itibaren başlayarak diğer çevredeki kişileri de içeren kişiler arası süreçlerle şekillenmektedir. Ele alınan duygular adaptif bir niteliğe de sahip olup gündelik hayatta davranışları düzenlemede ve yönlendirmede benlik için kritik bilgiler sağlamaktadır (Tagney, Miller, Flicker ve Barlow, 1996). İki duygu arasındaki temel fark kişinin kendisini ya da çevresini referans almasıdır. Utanç daha çok diğerleri tarafından onaylanmama, olumsuz benlik algısı gibi kavramlarla ilişkili olup diğerlerini referans alarak şekillenen bir duygusal tepkidir. Suçluluk ise utanç duygusuna göre daha özneldir; kişinin kendi içsel süreçlerini ve vicdanını referans almasıyla oluşan bir duygusal tepkidir (Tagney, 1996). Referans noktaları farklı olmasına rağmen olumsuz duyguları ve değerleri içermesi, kendini değerlendirme süreçlerini referans alması, benlik için kritik bilgiler sağlayarak davranışları düzenlemesi ve kişiler arası ilişkilerde deneyimlenmesi açısından suçluluk ve utanç duyguları birbiriyle örtüşen ve sıklıkla bir arada görülen ahlaki duygulardır (Ausubel, 1955; Lewis, 1971; Tagney vd., 1996; Tagney, Stuewig ve Mashek, 2007). Alan yazında suçluluk ve utancın psikopatoloji semptomlarıla ve somatik belirtilerle ilişkili olduğu da belirtilmektedir (Harder, Cutler ve Rockart, 1992; Pineless, Street ve Koenen, 2006; Tagney, Wagner ve Gramzow, 1992).

Somatik belirtiler kişiye acı çektirmekle kalmayıp davranışsal ve bilişsel süreçleri de etkileyerek ailesel-sosyal işlevsellikte sorunlara neden olmaktadır (Lipowski, 1987). Nitekim somatizasyonun prevelansının da arttığı belirtilmektedir (Sullivan ve Katon, 1993). Sağllk hizmetlerinden sıklıkla faydalanan bu hastaların, organik bozuklukla ilişkili olarak tedavi alan bireylere göre iki kat daha fazla bu hizmetlerden faydalandığı da ifade edilmekte ve uzun vadede yapılan ekonomik harcamalar da artmaktadır (Barsky, Orav ve Bates, 2005). Ülkemizde suçluluk, utanç ve bağlanma stillerinin somatizasyonla ilişkisini inceleyen çalışmalar sınırlı sayıdadır. Mevcut çalışmaların da sıklıkla suçluluk-utanç ve psikopatoloji ile bağlanma stilleri ve psikopatoloji arasındaki ilişkiye odaklandıkları görülmektedir. (Cirhingiroğlu ve Güvenç, 2011; Vatan, 2017). Suçluluk, utanç, bağlanma stilleri ve somatizasyon arasındaki ilişkinin bir bütün olarak değerlendirilmesinin ve bu değişkenlerin somatizasyonu yordama gücünün belirlenmesinin somatizasyonun doğasının anlaşılmasına katkıda bulunabileceği öngörülebilir. Nitekim yaşantılarını ve yaşantılarına ilişkin duygularını bedensel olarak ifade eden somatik popülasyonda erken dönem deneyimlerinin, bununla bağlantılı olarak ilişki kurmanın, kurulan ilişkide örtük olarak etki eden olumsuz duyguların çalışılması anlamlıdir.

Son yıllarda internete kolay erişimin kolay olması nedeniyle internet üzerinden sağlığa yönelik bilgi edinme davranışı artış göstermiştir (Doyle, Ruskin ve Engel, 1996). İnternette sağlığa yönelik araştırma yapma güvence arama davranışı ve kaygıyı yatıştırma ile ilişkilidir (Starcevic ve Berle, 2013). Erken dönemdeki çatışmaların somatik belirtilerle ilişkili olduğu düşünüldüğünde, çevrim içi yardım aramanın yani güvence arama davranışının bağlanma ve somatizasyon ile ilişkili olabileceği öngörülebilir. Dolayısıyla bu çevrim içi güvence arama, onay alma, endişeyi giderme davranış düzeyinin somatizasyon ve bağlanma stilleri puanları üzerinde etkili olup olmadığını incelemek de anlamlı görünmektedir. Bunun yanı sıra kadınlarda somatik şikayetler erkeklere göre daha sık görülmektedir (Aragona, Monteduro, Colosimo, Maisano ve Geraci, 2008). Cinsiyetler arası farklılık kültüre bağlı olarak değişmekle birlikte erken dönemde bakım verenle kurulan güvensiz ve kaygı içeren bağlanmanın bu farklılıkta rolü olabilir $(\mathrm{Li}, \mathrm{He}$ ve $\mathrm{Li}, 2009$ ).

$\mathrm{Bu}$ doğrultuda mevcut çalışmanın temel amacı üniversite öğrencilerinde somatizasyon, suçluluk, utanç, güvenli bağlanma, korkulu bağlanma, kayıtsız bağlanma ve saplantılı bağlanma değişkenleri arasındaki ilişkiyi incelemek; bağlanma stilleri ile suçluluk ve utanç duygularının somatizasyonu yordama gücünü belirlemektir. Çalışmanın bir diğer amacı ise internette sağlığa ilişkin araştırma yapma sıklığına göre bağlanma stili ve somatizasyon puanlarının değişip değişmediğini; cinsiyete göre somatizasyon, bağlanma stilleri ve suçluluk-utanç puanlarının farklılaşıp farklılaşmadığını ortaya koymaktır. 


\section{Yöntem}

\subsection{Araştırma Modeli}

Bu çalışmada değişkenler arasında ilişki kurmaya olanak veren olgudan sonra (ex post facto) alan araştırması türlerinden birisi olan tarama (survey) modeli kullanılmıştır.

\section{2. Örneklem}

$\mathrm{Bu}$ çalışmanın örneklemini Ondokuz Mayıs Üniversitesi Fen-Edebiyat Fakültesi'nde lisans eğitimine devam eden 1731 yaş aralı̆ğında $(20.05 \pm 1.81), 120$ kadın ve 92 erkek olmak üzere toplam 212 sağlıklı katılımcı oluşturmaktadır. Ancak uç değer özelliği gösteren 8 katılımcı araştırma örnekleminden çıkartılmıştır (Bkz. 2.4. İstatistiksel Analiz). Araştırmanın nihai örneklemini 17-26 yaş aralığında, 117 kadın $(19.58 \pm 1.72)$ ve 87 erkek $(20.69 \pm 1.75)$ olmak üzere toplam 204 katılımcı oluşturmuştur. Fen-Edebiyat Fakültesinde tarih, biyoloji, felsefe, istatistik, psikoloji, matematik ve sosyoloji bölümünde okuyan gönüllü katılımcılar araştırma örneklemine basit seçkisiz örnekleme tekniği uyarınca dahil edilmiştir. Araştırmanın yürütülebilirliğine ilişkin Ondokuz Mayıs Üniversitesi Sosyal ve Beşeri Bilimler Etik Kurulu tarafından izin alınmıştır (Karar no: 2019-268).

\section{3. İșlem}

Veriler toplanırken katılımcılara kişisel bilgilerinin gizli tutulacağı, çalışma verilerinin bilimsel araştırma dışında herhangi bir kurum ve kimse ile paylaşılmayacağı; katılma kararının gönüllülük ilkesine dayandığı belirtilmiştir. Gönüllü katılımcılar araştırma hakkında bilgilendirilmiş olup yazılı onam alınmıştır.

Uygulamalar sınıflarda yürütülmüştür. Öğrenciler bu katılım için herhangi bir ek not ve/veya puan almamıştır. Ölçeklerin katılımcılara uygulanma sırası tam dengeleme tekniği uyarınca belirlenmiştir. İlk katılımcı için uygulanma sırası seçkisiz olarak belirlenmiş, takip eden katılımcılar için ölçekler birer sıra kaydırılarak uygulanmıştır.

\subsection{Veri Toplama Araçları}

Bu çalışmada katılımcıların sosyo-demografik özelliklerine ilişin bilgiler bir bilgi toplama formuna kaydedilmiştir. Katılımcılara Suçluluk ve Utanç Ölçeği, İlişki Ölçekleri Anketi ve Belirti Tarama Listesi'nin somatizasyon alt ölçeği uygulanmıştır.

\subsubsection{Belirti Tarama Listesi}

Derogatis (1977) tarafından geliştiren Ruhsal Belirti Tarama Listesi (SCL-90-R: Symptom Checklist 90 Revised) bireylerdeki psikolojik belirtilerin hangi alanda olduğunu ve ilgili semptomların düzeyini belirlemek üzere geliştirilmiş bir ölçme aracıdır. Ölçek 90 maddeden oluşmakta olup bireylerden son bir ayı göz önüne alarak ölçek maddelerini 0-4 arası puanlaması istenmektedir. SCL-90-R;Depresyon, Kayg1, Obsesif-Kompulsif, Somatizasyon, Fobik Kayg1, Kişilerarası Duyarlık, Düşmanlık, Paranoid Düşünce ve Psikotizm olmak üzere 9 alt ölçekten oluşmaktadır (Derogatis, Rickels ve Rock, 1976).

Ölçeğin Türkiye örneklemi için geçerlik ve güvenilirlik çalışmaları Dağ (1991) ve Kılıç (1991) tarafindan üniversite öğrencileri üzerinde yürütülmüştür. Dağ (1991) ölçeğin Minnesota Çok Yönlü Kişilik Envanteri (MMPI: Minnesota
Multiple Personality Inventory), Beck Depresyon Ölçeği ve Sürekli Kaygı Ölçeği ile korelasyonuna bakmış olup ilgili korelasyon katsayılarının $.33-.81$ arasında değiștiğini bulmuştur. Dă̆ (1991) genel semptom düzeyine göre Cronbach alfa iç tutarlı̆̆ını .97; ölçeğin test-tekrar test güvenirlik katsayılarının ise .65 ile .87 arasında değiştiği bulmuştur. Kılıç (1991), MMPI ile SCL-90-R arasındaki korelasyon katsayılarının .40-.59 arasında değiştiğini; somatizasyon alt ölçeği için test tekrar test güvenilirlik katsayısını .82 bulunmuştur. SCL-90-R' nin ruh sağlığı riskli grupları tespit etmede geçerli ve güvenilir bir ölçüm aracı olduğu görülmüştür. Genel semptom ortalamasındaki yüksek puanlar, bireylerdeki psikolojik ya da bedensel zorlanma semptomlarından duyulan sıkıntının artışına işaret etmektedir. Alt ölçek puanları da ilgili boyuttaki belirti yoğunluğunu göstermekte ve kapsadıkları maddelerin ağırlıklı ortalama puanlarının alınması yoluyla hesaplanmaktadır. Mevcut çalışmada SCL-90-R' nin somatizasyon alt ölçeği kullanılmıştır. Yüksek puanlar yüksek somatizasyon düzeyini göstermektedir.

\subsection{2. İlişki Ölçekleri Anketi}

İlişki Ölçekleri Anketi Griffin ve Bartholomew (1994)'un tarafindan güvenli, korkulu, kayıtsız ve saplantılı bağlanma olmak üzere dört farklı bağlanma stilini değerlendirmek için geliştirilen ve 30 maddeden oluşan yedili Likert tipi bir ölçektir. Alt ölçeklerden alınan yüksek puan bireyde ilgili bağlanma stilinin baskın olduğuna işaret etmektedir. Türkiye örneklemi için geçerlik ve güvenilirlik çalışmaları Sümer ve Güngör (1999) tarafindan yürütülmüştür. Ölçeğin 17 madde olmak üzere, dört farklı bağlanma stilini ölçtüğü bir diğer anlatımla dört faktörden oluştuğu görülmüştür. İlgili çalışmada güvenirlik katsayılarının .41 ile .71 arasında olduğu; test-tekrar test güvenilirlik katsayılarının ise .54 ile .78 arasında değiştiği ifade edilmiştir. Alt ölçeklere iliş̧kin iç tutarlık katsayılarının ise .27 ile .61 arasında değiștiği görülmüştür. Düşük katsayıların farklı modellerin aynı stil içinde olmasından kaynaklandığı belirtilmiştir. Alt ölçeklerin güvenilirlikleri düşük olmasına rağmen yapı geçerliklerinin yeterli düzeyde olduğu da ifade edilmiştir. Mevcut çalışmada bağlanma stilleri söz konusu testten elde edilen dört puan ile hesaplanmıştır.

\subsubsection{Suçluluk ve Utanç Ölçeği}

Şahin ve Şahin (1992) tarafından çeşitli durumlarda yaşanan ve depresyonla ilişkili olduğu ileri sürülen suçluluk ve utanç duygularını belirleyebilmek üzere geliştirilen ölçek, toplam 24 maddeden oluşmakta olup 1-5 arasında puanlanan Likert tipi bir ölçektir. Geçerlik çalışmasında ölçeğin suçluluk ve utanç olmak üzere iki boyuttan oluştuğu görülmüştür. Ölçeğin Beck Depresyon Envanteri ile suçluluk alt ölçeğinin korelasyon katsayıs1 -.10 iken sosyotropi ölçeği ile .33 bulunmuştur. Utanç ölçeğinin sosyotropi ölçeği ile korelasyon katsayısı ise .50 bulunmuştur. Suçluluk ve utanç olmak üzere iki alt boyuttan oluşan ölçeğin, suçluluk alt ölçeği için Cronbach alfa katsayısı .81 iken utanç alt ölçeği için .80 'dir. Suçluluk ve utanç alt ölçeğinden alınan yüksek puanlar iki duygunun da yüksek düzeyde olduğunu göstermektedir.

\section{5. İstatistiksel Analiz}

Analizlere başlanmadan önce verilerin yaş açısından uç değer gösterip göstermediği incelenmiştir. Buna göre yaş 
açısından $\mathrm{z}$ puanı \pm 3,29 aralığını aşan altı katılımcı araştırma örnekleminden çıkarılmıştır. Suçluluk, utanç, somatizasyon ve bağlanma stilleri (güvenli, korkulu, kayıtsız, saplantılı) değişkenlerinde uç değer olup olmadığı tek değişkenli uç değer analizi ile belirlenmiştir. Her bir değişken için ilgili z puanları incelendiğinde, utanç ve kayıtsız bağlanma değişkenlerinde $\mathrm{z}$ puanları \pm 3.29 aralığını aşan iki katılımcı araştırma örnekleminden çıkarılmıştır.

Uç değerler çıkartıldıktan sonra verilerin normal dağılım sayıltısını karşılama durumu basıklık ve çarpıklık katsayısı, Kolmogorov Simirnov değeri ve histogram grafiğine bakılarak değerlendirilmiştir. Normal dağılım koşulunu sağlayan verilere parametrik istatistiksel analizler uygulanmıştır.

Suçluluk, utanç, güvenli bağlanma, korkulu bağlanma, kayıtsız bağlanma, saplantılı bağlanma ve somatizasyon puanları arasındaki ilişki katsayısı Pearson Momentler Çarpımı Korelasyon Analizi ile belirlenmiştir. Suçluluk, utanç, güvenli bağlanma, korkulu bağlanma, kayıtsız bağlanma ve saplantılı bağlanma puanlarından hangilerinin somatizasyon puanını anlamlı bir şekilde yordadığını belirlemek amacıyla Aşamalı Regresyon (Stepwise) analizi uygulanmıştır.

Somatizasyon, suçluluk, utanç, güvenli bağlanma, korkulu bağlanma, kayıtsız bağlanma, saplantılı bağlanma puanlarının cinsiyet değişkeni açısından farklılaşıp farklılaşmadığı MANOVA (Çok Değişkenli Varyans Analizi) ile incelenmiştir. Somatizasyon, güvenli bağlanma, korkulu bağlanma, kayıtsız bağlanma ve saplantılı bağlanma puanlarının internette sağlığa ilişkin araştırma yapma düzeyine göre değişip değişmediği de MANOVA ile incelenmiştir. İstatistiksel analizler SPSS (Version 20) programı ile yürütülmüştür.

\section{Bulgular}

\subsection{Suçluluk, Utanç, Bağlanma Stilleri Ve} Somatizasyon Arasındaki İlişkiye Yönelik Bulgular

Suçluluk, utanç, güvenli bağlanma, korkulu bağlanma, kayıtsız bağlanma, saplantılı bağlanma ve somatizasyon puanları arasındaki ilişki katsayısı Pearson Momentler Çarpımı Korelasyon Analizi ile belirlenmiştir. Somatizasyon puanları ile suçluluk, utanç, korkulu bağlanma ve saplantılı bağlanma arasında, .26 ile .47 katsayılarında değişen pozitif yönde anlamlı ilişkiler bulunmuştur (Tablo 1). Somatizasyon ile güvenli bağlanma arasında negatif yönde anlamlı bir ilişki bulunmuştur $(\mathrm{p}<.001)$.

Tablo 1'de görüldüğü üzere en yüksek korelasyon katsayısı suçluluk ve utanç puanları arasında olup .54 düzeyinde anlamlı bir ilişki bulunmaktadır $(\mathrm{p}<.001)$. Suçluluk puanı ile korkulu bağlanma $(\mathrm{p}<.05)$ ve saplantılı bağlanma $(\mathrm{p}<$ .001) puanları arasında pozitif yönde anlamlı bir ilişki bulunmuştur. Utanç puanı ile korkulu bağlanma ve saplantılı bağlanma puanları arasında pozitif yönde, güvenli bağlanma puanı ile negatif yönde anlamlı bir ilişki bulunmuştur $(\mathrm{p}<$ .001). Güvenli bağlanma ile korkulu bağlanma ve saplantılı bağlanma puanları arasında negatif yönde; korkulu bağlanma ile kayıtsız ve saplantılı bağlanma puanları arasında pozitif yönde anlamlı bir ilişki bulunmuştur ( $\mathrm{p}<$ .001). Kayıtsız bağlanma ile suçluluk ve utanç duyguları arasında; güvenli bağlanma ile suçluluk arasında; kayıtsız ve saplantılı bağlanma arasında anlamlı bir ilişki bulunmamıștır.

\subsection{Suçluluk, Utanç Ve Bağlanma Stilleri Puanlarının Somatizasyonu Yordamasina Illişkin Bulgular}

Aşamalı regresyon analizi öncesinde verilerin analizin sayıltılarını karşılama durumu incelenmiştir. Tabachnick ve Fidell (2015: 122-160)'e göre regresyon analizi için örneklem büyüklüğü [50 + (8x yordayıcı değișken $)]$ eșitliği ile belirlenmektedir. Buna göre örneklem büyüklüğünün regresyon analizi için yeterli olduğu görülmektedir. Regresyon analizi için uç değerler Mahalanobis ile incelendiğinde, altı yordayıcı değişkenin bulunduğu modelde herhangi bir uç değerin bulunmadığı görülmüştür. Çoklu bağlantısallık açısından veriler incelendiğinde, varyans büyütme faktörlerinin (VIF <10) ve tolerans değerlerinin (tolerans $>$.10) kabul edilebilir aralıkta olduğu görülmüştür. Yordayıcı ve yordanan değişkenler arasındaki korelasyon katsayılarının ağırlıklı olarak .30'dan büyük olması ve yordayıcı değişkenler arasındaki ilişki katsayılarının da .70'den küçük olması nedeniyle veriler arasında çoklu bağlantısallık problemi bulunmamaktadır.

Suçluluk, utanç ve bağlanma stilleri puanlarından hangilerinin somatizasyon puanını anlamlı bir şekilde yordadığını belirlemek amacıyla Aşamalı Regresyon (Stepwise) analizi yürütülmüştür (Tablo 2). Aşamalı regresyon analizi sonucunda elde edilen nihai modelde güvenli bağlanma, utanç, saplantılı bağlanma ve korkulu bağlanma puanlarının somatizasyon puanını yordadığı ve ilgili değiş̧kenlerin varyansın \%36'sını $\left(\mathrm{R}=.59, \mathrm{R}^{2}=.36\right.$ ve $\left.\mathrm{R}^{2}{ }_{\text {adj }}=.34\right)$ açıkladığ görülmüştür $\left(\mathrm{F}_{4-199}=26.42, \mathrm{p}<.001\right)$. 
Tablo 1. Suçluluk, Utanç, Güvenli Bağlanma, Korkulu Bağlanma, Kayıtsız Bağlanma, Saplantılı Bağlanma ve Somatizasyon Puanları Arasındaki Korelasyon Analizi

\begin{tabular}{|c|c|c|c|c|c|c|c|}
\hline & 1 & 2 & 3 & 4 & 5 & 6 & 7 \\
\hline 1. Suçluluk & 1.00 & & & & & & \\
\hline 2. Utanç & $.54 * * *$ & 1.00 & & & & & \\
\hline 3. Güvenli & -.11 & $-.32 * * *$ & 1.00 & & & & \\
\hline 4. Korkulu & $.16^{*}$ & $.31 * * *$ & $-.36 * * *$ & 1.00 & & & \\
\hline 5. Kayitsız & .07 & .03 & .03 & $.38 * * *$ & 1.00 & & \\
\hline 6. Saplantılı & $.24 * * *$ & $.41 * * *$ & $-.35 * * *$ & $.36 * * *$ & .17 & 1.00 & \\
\hline 7.Somatizasyon & $.26 * * *$ & $.42 * * *$ & $-.44 * * *$ & $.47 * * *$ & .10 & $.43 * * *$ & 1.00 \\
\hline
\end{tabular}

$* * * p<.001 * * p<.01 * p<.05$

Tablo 2. Somatizasyonu Yordayan Değişkenlerin B, $\beta$ Katsayıları ve Anlamlılık Düzeyleri

\begin{tabular}{|c|c|c|c|c|c|c|}
\hline & Yordayıcılar & B & SS & B & $\mathrm{t}$ & $\mathrm{p}$ \\
\hline & Sabit & 3.23 & 4.84 & & .67 & .506 \\
\hline \multirow[t]{4}{*}{ Model } & Güvenli Bağlanma & -.479 & .121 & -.255 & -3.96 & .000 \\
\hline & Utanç & .257 & .076 & .218 & 3.37 & .001 \\
\hline & Saplantılı Bağlanma & .446 & .143 & .207 & 3.11 & .002 \\
\hline & Korkulu Bağlanma & .263 & .125 & .135 & 2.09 & .038 \\
\hline
\end{tabular}

Standartlaşmış regresyon katsayılarına göre yordayıcı değişkenlerin somatizasyon üzerindeki göreli önem sırası güvenli bağlanma $(\beta=-.48, \mathrm{p}<.005)$, saplantılı bağlanma $(\beta$ $=.45, \mathrm{p}<.005)$, korkulu bağlanma $(\beta=.26, \mathrm{p}<.05)$ ve utanç $(\beta=.25, \mathrm{p}<.005)$ şeklindedir (Tablo 2). Güvenli bağlanmanın somatizasyonu negatif yönde, modelde yer alan diğer değişkenlerin ise pozitif yönde yordadığı görülmüştür. Modele göre somatizasyonu yordayan regresyon denklemi "Somatizasyon $=(-.48 \times$ güvenli bağlanma puanı $)+(.45 \mathrm{x}$ saplantılı bağlanma $)+(.26 \times$ korkulu bağlanma $)+(.25 \mathrm{x}$ utanç puan1) +3.23 " olarak elde edilmiştir.

\subsection{Cinsiyete ilişskin bulgular}

Analiz öncesinde veriler MANOVA analizi sayıltılarını karşılama durumu açısından değerlendirilmiştir. Değişkenler arasında çoklu bağlantısallık problemi bulunmamaktadır $(\mathrm{r}<$ .70). Çoklu birlikte doğrusallık varsayımlarının kontrolüne ilişkin sonuçlar kabul edilebilir niteliktedir. Hata varyanslarının eşitliği Levene Testi ile değerlendirilmiştir. Levene testine göre suçluluk $(p=.000)$ ve utanç $(p=.049)$ değişkenlerinin cinsiyet açısından homojen olmadığı, diğer taraftan bağlanma stilleri ve somatizasyon puanlarının hata varyansları eşitliğini karşıladığ̣ görülmüştür $(p>.05)$.
Varyans kovaryans matrislerinin homojenliği koşulu sağlanamadığı $(\mathrm{p}=.019)$ için analiz sonuçları Pillai İz (Pillai's Trace) değerlerine göre değerlendirilmiştir. MANOVA analizine göre kadın ve erkek katılımcıların birleşik bağımlı değişken puanları arasında anlamlı bir farklılık bulunduğu görülmüştür (Pillia $\dot{I} z=.15, \mathrm{~F}_{7-196}=.15$, $\left.\mathrm{p}<.001, \mathrm{\eta}^{2}=.15\right)$.

Katılımcıların cinsiyetine göre suçluluk, utanç, güvenli bağlanma, korkulu bağlanma, kayıtsız bağlanma, saplantılı bağlanma ve somatizasyon puanlarına yönelik aritmetik ortalama ve standart sapma değerleri Tablo 3'te özetlenmiştir. Suçluluk, utanç, güvenli bağlanma, saplantılı bağlanma ve somatizasyon puanlarının her biri için cinsiyet temel etkisi anlamlı bulunmuştur (Tablo 4). Cinsiyetin suçluluk, utanç ve güvenli bağlanma puanları üzerindeki etki büyüklüğü orta düzeyde iken, saplantılı bağlanma üzerindeki etki büyüklügü ise düşük düzeydedir. İlgili ortalamalar incelendiğinde kadınların suçluluk, utanç, saplantılı bağlanma ve somatizasyon puanlarının erkeklere göre yüksek olduğu; güvenli bağlanma puanlarının ise düşük olduğu görülmüştür (Tablo 3). Korkulu ve kayıtsız bağlanma açısından cinsiyetler arasında anlamlı bir farklılık bulunmamıştır. 
Tablo 3: Suçluluk, Utanç, Güvenli Bağlanma, Korkulu Bağlanma, Kayıtsız Bağlanma, Saplantılı Bağlanma, Somatizasyon Puanlarına İlişkin Aritmetik Ortalama ve Standart Sapma Değerleri

\begin{tabular}{lcc}
\hline & Kadın & Erkek \\
$(\mathrm{n}=117)$ & $\overline{\mathrm{n}=87)}$ \\
& $\bar{X} \pm S S$ & $\bar{X} \pm S S$ \\
Suçluluk & $51.18 \pm 5.87$ & $46.75 \pm 9.19$ \\
Utanç & $42.80 \pm 6.63$ & $39.12 \pm 8.27$ \\
Güvenli & $18.59 \pm 4.95$ & $21.25 \pm 4.01$ \\
Korkulu & $16.12 \pm 4.76$ & $14.92 \pm 4.27$ \\
Kayitsız & $21.91 \pm 5.40$ & $21.87 \pm 5.05$ \\
Saplantılı & $16.15 \pm 3.97$ & $14.78 \pm 8.32$ \\
Somatizasyon & $17.48 \pm 8.32$ & $12.65 \pm 8.98$ \\
\hline
\end{tabular}

Tablo 4: Cinsiyete göre Suçluluk, Utanç, Güvenli Bağlanma, Korkulu Bağlanma, Kayıtsız Bağlanma, Saplantılı Bağlanma ve Somatizasyon Puanlarına İlişkin MANOVA Sonuçları

\begin{tabular}{|c|c|c|c|c|c|}
\hline & Kaynak & $\mathrm{Sd}$ & $\mathrm{F}$ & $\mathrm{P}$ & $\eta 2$ \\
\hline \multirow[t]{2}{*}{ Suçluluk } & Grup & 1 & 17.60 & .000 & .08 \\
\hline & Hata & 202 & & & \\
\hline \multirow[t]{2}{*}{ Utanç } & Grup & 1 & 12.42 & .001 & .06 \\
\hline & Hata & 202 & & & \\
\hline \multirow[t]{2}{*}{ Güvenli Bağlanma } & Grup & 1 & 16.91 & .000 & .08 \\
\hline & Hata & 202 & & & \\
\hline \multirow[t]{2}{*}{ Korkulu Bağlanma } & Grup & 1 & 3.46 & .064 & .02 \\
\hline & Hata & 202 & & & \\
\hline \multirow[t]{2}{*}{ Kayıtsız Bağlanma } & Grup & 1 & .000 & .956 & .00 \\
\hline & Hata & 202 & & & \\
\hline Saplantılı Bağlanma & $\begin{array}{l}\text { Grup } \\
\text { Hata }\end{array}$ & $\begin{array}{c}1 \\
202\end{array}$ & 5.62 & .019 & .03 \\
\hline Somatizasyon & Grup & 1 & 15.57 & .000 & .07 \\
\hline
\end{tabular}

\subsection{Internette să̆lı̆̆a iliş̧kin araştırma yapma sikliğına yönelik bulgular}

Katılımcıların internet üzerinden sağlığa ilişkin araştırma yapma sıklığı hiç, nadiren ve sık olmak üzere üç düzeyde belirlenmiştir. Buna göre 48 (\%23.5) katılımcının internet üzerinden sağlığa ilişkin hiç araştırma yapmadı̆̆ı, 82 (\%40.2) katılımcının nadiren ve 74 (\%36.3) katılımcının ise sıklıkla internetten sağlığa ilişkin araştırma yaptığı görülmüştür.

MANOVA analizi öncesi sayıltılar incelenmiştir. Levene Testi ile değerlendirilen hata varyansları eşitliğinin karşılandığ1 görülmüştür $(\mathrm{p}>.05)$.
Varyans kovaryans matrislerinin homojenliği koşulu sağlanamamıştır $(\mathrm{p}=.028)$. Bu nedenle analiz sonuçları Pillai İz (Pillai’s Trace) değerlerine göre değerlendirilmiştir. Her iki grubun birleşik bağımlı değişken puanları arasında anlamlı bir farklılık bulunduğu görülmüştür (Pillia $\dot{I} z=.15$, $\left.\mathrm{F}_{12-394}=2.61, \mathrm{p}<.002, \mathrm{\eta}^{2}=.07\right)$.

Katılımcıların internette sağlığa ilişkin araştırma yapma sıklığına göre güvenli, korkulu, kayıtsız, saplantılı bağlanma ile somatizasyon puanlarına ilişkin betimleyici istatistikler Tablo 5'te özetlenmiştir. 
389 Gerdan, G. \& Kurt, M. / Anemon Muş Alparslan Üniversitesi Sosyal Bilimler Dergisi, 2020 8(2) 383-393 
Tablo 5: İnternette Sağlığa İlişkin Araştırma Yapma Düzeyine Göre Güvenli Bağlanma, Korkulu Bağlanma, Kayıtsız Bağlanma, Saplantılı Bağlanma ve Somatizasyon Puanlarına İlişkin Aritmetik Ortalama ve Standart Sapma Değerleri

\begin{tabular}{lccc}
\hline & Hiç & Nadir & Sik \\
$(\mathrm{n}=48)$ & $(\mathrm{n}=82)$ & $74)$ \\
$\bar{X} \pm S S$ & $18.22 \pm 4.55$ \\
Güvenli & $\bar{X} \pm S S$ & $\bar{X} \pm S S$ & $16.07 \pm 4.81$ \\
Korkulu & $21.35 \pm 4.31$ & $15.79 \pm 4.30$ & $22.05 \pm 5.65$ \\
Kayıtsız & $14.58 \pm 4.65$ & $22.34 \pm 5.18$ & $16.34 \pm 4.75$ \\
Saplantılı & $20.90 \pm 4.64$ & $15.21 \pm 3.59$ & $18.95 \pm 9.48$ \\
Somatizasyon & $15.00 \pm 3.88$ & $14.33 \pm 8.83$ & \\
\hline
\end{tabular}

Tablo 6: İnternette Sağlığa İlişkin Araştırma Yapma Sıklığına göre Güvenli Bağlanma, Korkulu Bağlanma, Kayıtsız Bağlanma, Saplantılı Bağlanma ve Somatizasyon Puanlarına İlişkin MANOVA Sonuçları

\begin{tabular}{lccccc}
\hline & Kaynak & Sd & F & P & . \\
Güvenli Bağlanma & Grup & 2 & 7.28 & .001 & .07 \\
Korkulu Bağlanma & Hata & 201 & & .02 \\
Kayıtsız Bağlanma & Hata & 201 & 1.64 & .302 & .01 \\
Saplantılı Bağlanma & Grup & 2 & 1.20 & .129 \\
Hata & 201 & & .02 \\
Somatizasyon & Grup & 2 & 2.07 & .001 \\
\hline
\end{tabular}

Güvenli bağlanma ve somatizasyon puanları, internette sağlığa ilişkin araştırma yapma sıklığına göre anlamlı bir farklılık göstermektedir (Tablo 6). Söz konusu yordayıcı değişkenin güvenli bağlanma ve somatizasyon puanlarındaki değişimi açıklama gücü orta düzeydedir. Kayıtsız, saplantılı ve korkulu bağlanma puanlarının internette araştırma yapma sıklığına göre değişmediği görülmüştür.

Güvenli bağlanma açısından internette sağlığa ilişkin araştırma yapma sıklığına göre hangi gruplar arasında anlamlı bir farklılık olup olmadığını belirlemek için En Az Anlamlı Farklar Testi (Least Significant Difference) uygulanmıştır. Test sonucuna göre, internette sağlığa ilişkin sık araştırma yapanlar (18.22 \pm 4.55$)$ ile hiç yapmayanlar $(21.35 \pm 4.32)$ ve nadiren araştırma yapanlar $(20.13 \pm 4.82)$ arasında anlamlı bir farklılı bulunmaktadır $(\mathrm{p}<.01)$. İnternette sağlığa ilişkin sık araştırma yapanların güvenli bağlanma puanları diğer gruplara (hiç ve nadiren) göre düşüktür. Diğer taraftan hiç araştırma yapmayanlar ile nadiren araştırma yapanlar arasında anlamlı bir fark bulunmamaktadır $(\mathrm{p}>.05)$.

\section{Tartışma, sonuç ve öneriler}

Mevcut çalışmada somatizasyonun suçluluk, utanç ve bağlanma stilleri ile ilişkisi incelenmekle birlikte cinsiyet değişkeni açısından puan örüntülerinin farklılaşıp farklaşmadığı ve internette sağlığa yönelik araştırma yapma sıklığının da somatizasyon ve bağlanma stili puanları üzerinde etkisi olup olmadığı incelenmiştir.

Çalışmada güvenli bağlanmanın, utancın, saplantılı bağlanmanın ve korkulu bağlanmanın somatizasyon puanlarının \%36'sını yordadığı bulunmuştur. Korelasyonel analizlerde de somatizasyon puanı arttıkça korkulu ve saplantılı bağlanma puanlarının arttığı, güvenli bağlanma puanlarının azaldığı ve suçluluk-utanç puanlarının da arttığı bulunmuştur. Kayıtsız bağlanma puanı ile somatizasyon puanı arasında ise anlamlı bir ilişki saptanmamıştır.

Alanyazında da mevcut araştırmanın bulguları ile paralel olarak güvenli bağlanma ile somatik semptomlar arasında negatif bir ilişki olduğu; özellikle korkulu ve saplantılı bağlanmanın somatizasyonla ilişkili bulunduğu; kaygı ve korku ağırlıklı bağlanan kişilerin somatik şikayetleri ile bağlantılı olarak sağlık hizmetlerinden daha çok faydalandığı ifade edilmektedir (Ciechanowski vd., 2002; Kidd ve Sheffield, 2005; Liu, Cohen, Schulz ve Waldinger, 2011; Waldinger, Schulz, Barsky ve Ahern, 2006; Noyes vd., 2003). Güvenli bağlanan bireylerde somatik şikayetlerin azalmasıyla birlikte öfke gibi duyguları ifade edebildikleri, korku ve kaygı ağırlıklı bağlanan bireylerin ise bu duyguları baskıladığı da ifade edilmektedir (Liu vd., 2011). Güvenli bağlanma ile psikolojik sağlamlık arasında da pozitif bir ilişki olduğu; güvenli bağlanma arttıkça psikolojik sağlamlığın arttığı, korkulu ve kaygılı bağlanma arttıkça 
psikopatoloji eğiliminin arttığı (Sümer vd., 2009; Karaırmak ve Güloğlu, 2014) da bulunmuştur. Bunun yanı sıra araştırma bulguları ile paralel olarak kayıtsız bağlanma ile psikolojik sağlamlık arasında anlamlı bir ilişki bulunmadığı belirtilmiştir (Karaırmak ve Güloğlu, 2014).

Mevcut çalışmada suçluluk ve utanç duygularının somatizasyonla ilişkili olduğu ancak utanç duygusunun somatizasyonun önemli bir yordayıcısı olduğu ortaya konmuştur. Nitekim suçluluk ve utancın psikopatolojik ve/veya somatik belirtilerle ilişkili olduğu; utancın somatik belirtileri daha fazla yordadı̆̆ı; suçluluk ve utancın bağ 1 şıklık sisteminin direncini etkilediği ifade edilmektedir (Dickerson, Kemeny, Aziz, Kim ve Fahey, 2004; Harder vd., 1992; Pineless vd., 2006).

Çalışma bulguları aynı zamanda bireyin erken dönemdeki bağlanma stilleri ile suçluluk-utanç duyguları arasındaki ilişkiye de işaret etmektedir. Güvenli bağlanma ile utanç negatif yönde ilişkili iken, saplantılı ve korkulu bağlanma ile utanç pozitif yönde ilişkili bulunmuştur. Bir diğer anlatımla, güvenli bağlanma arttıkça utanç duygusu azalmakta; birey yakınlık kurmaktan çekinmedikçe diğerleri tarafından onaylanma ve reddedilmeye duyarlılık ile ilişkili olan utanç duygusuna girmemektedir. Çalışmada, suçluluk ile saplantılı ve korkulu bağlanma arasında ise pozitif yönde bir ilişki bulunmuştur. Suçluluk arttıkça saplantılı bağlanmanın yanı sıra kayg1-korku ile diğerlerine tutunma eğilimi de artmaktadır. Alanyazındaki çalışmalar da mevcut bulguları destekler niteliktedir. Güvenli bağlanmadaki artışın utanç duygusundaki azalmayı yordadığı, kaygı ve korku içerikli bağlanma örüntüsü ile utancın ilişkili olduğu belirtilmektedir. Suçluluğun ise reddedilme korkusu ve aşırı onay alma/aramanın baskın olduğu korku ve kaygı içeren bağlanma eğilimleri ile ilişkili olduğu gösterilmiştir (Akbağ ve İmamoğlu, 2010; Bartholomew ve Horowitz, 1991; Pineless vd., 2006)

Mevcut bulgular kuramsal açıklamalarla da örtüşmektedir. Somatik şikayetleri olan bireyler duygularını anlatmada sözcüklerle kurulu olan dili değil, organ dilini seçmektedirler (Lesser, Ford ve Friedmann, 1979). Bir diğer anlatımla, bu kişilerde duygular fiziksel belirtilerle ifade edilmektedir. Güvenli bir şekilde ebeveyne bağlanamayan kaygılı süreçlerin hakim olduğu bağlanma örüntülerine sahip birey, kaotik kişiler arası etkileşim içine girmekte ve erken dönemde edinemediği bakımı ve ilgiyi yetişkinlikte somatik belirtiler ile edinmeye çalışmaktadır (Stuart ve Noyes, 1999). İçselleştirilmiş ebeveyn yasakları ile katılaşan üst benlik suçluluk-utanç duyguları ile yakından ilişkilidir. Bu noktada bağlanma temsilleri de tehditkar olarak işlemlenmekte olup suçluluk ve utanç belli bir organa yatırılmakta yani çatışma bedene taşınmaktadır (Meissner, 2006).

Çalışmada cinsiyet açısından somatizasyon, suçluluk, utanç ve bağlanma stilleri puanları arasında anlamlı bir farklılık bulunmuştur. Kadınların somatizasyon, suçluluk-utanç ve saplantılı bağlanma puanları erkeklere göre daha yüksek bulunmuştur. Güvenli bağlanma puanlarının ise erkeklere göre düşük olduğu bulunmuştur. Alan yazındaki çalışmalar da kadınların erkeklere göre daha fazla somatik belirtileri ve yakınmaları olduğunu göstermektedir (Aragona vd., 2008; Harvey, Gore, Frank ve Batres, 1997). Suçluluk-utanç duygularının da kadınlarda erkeklere göre daha fazla olmasının yanı sıra (Tangney vd., 1996; Harvey vd., 1997), kadınların ilişkideki yakınlığa ve reddedilmeye daha duyarlı olduğu (Barry, Seager ve Brown, 2015) belirtilmiştir. Nitekim Woien, Ernst, Patock-Peckham ve Nagoshi (2003)'a göre erken dönemde kurulan olumsuz ilişkiler, suçluluk ve utanç duyma eğilimini artırmaktadır. Çalışma bulguları ve alanyazın bütün olarak değerlendirildiğinde, erken dönemde güvenli temsillere sahip olmayan ve kayg1korku içeren bağlanma stillerine yatkın olan kadınların, duygularını beden dili aracılığıyla ifade etmeye yatkın olmalarının yanı sıra suçluluk ve utanç duygularına temas etmeye de yakın oldukları söylenebilir. Bir diğer perspektif ise toplumlarda hastalığın kadınsı görünmesine, kadınsılaştırılmasına vurgu yaparak kültürel ve sosyal tutumlara işaret etmektedir (Wool ve Barsky, 1994). Bu durum kültür ve kültürel tutumların da cinsiyetler arası farklılıkta rol oynadığını düşündürmektedir.

Araştırmada internette sağlığa yönelik sık araştırma yapan katılımcıların somatizasyon puanları yüksek bulunmakla birlikte güvenli bağlanma puanlarının da nadir ve hiç araştırma yapmayan gruplara göre düşük olduğu bulunmuştur. Literatürde de sağlığa ilişkin kaygı taşıyanların internet üzerinden s1k sık çare arayışına ve/veya tanı arayışına girdikleri belirtilmekle birlikte (Eastin ve Guinsler, 2006), çevrim içi sağlık bilgisi edinme davranışının sağlığa yönelik kaygıyı artırdığını da rapor etmektedir (White ve Horvitz, 2009). Stuart ve Noyes (1999) ise somatik şikayetler ile bağlanma ilişkisine vurgu yaparak, sağlığa yönelik kaygıların güvensiz bağlanma ile tetiklenen kişiler arası bir davranış olduğunu ifade etmektedir. Birey somatik şikayetleri aracılığı ile destek almanın yanı sıra başkalarından bu şekilde güvence alarak güvende ve rahat hissetmeye çalışmaktadır. Güvensiz bağlanmanın tetiklediği somatik kaygıları rahatlatmak üzere hekimlerden ya da yakınlarındaki kişilerden güvence ve onay arayan bu kişiler, uzun vadede kişiler arası ilişkilerde olumsuzluklarla karşılaşmanın yanı sıra yabancılaşma da yaşamaktadır. Bu yabancılaşma da terk edilme olarak yorumlanabilmekte ve sağlığa yönelik kaygıları da arttırmakta ve kişi tekrar tekrar somatik şikayetlerine çare arama döngüsüne girmektedir (Waldinger vd., 2006). Bir nevi erken dönemde edinemediği güvensizliğe ilişkin psikolojik yapılar ve geçmiş öğrenmeler tekrar tekrar sahnelenmektedir.

Araştırmanın bir takım sınırlılıkları bulunmaktadır. Örneklemin sadece üniversite öğrencilerinden oluşmasının yanı sıra verilerin tek bir fakülteden toplanması araştırmanın bir sınırlılığıdır. Farklı örneklem grupları ile yürütülecek çalışmalarla ilgili değişkenler arasındaki ilişki örüntüsü incelenebilir. Ayrıca mevcut çalışma, klinik popülasyon ile yürütülmemiş olup sağlıklı olduğu düşünülen üniversite öğrencileri ile yürütülmüştür. Klinik popülasyon ile karşılaştırma çalışmaları yapılmasının gerek teorik gerekse uygulamalı alanlarda önemli bilgiler sağlayacağı düşünülmektedir.

Sonuç olarak, bireyin erken dönemde kurduğu yakınlıkları referans alarak mevcut ilişkilerinde olumlu ve güvenli bir ilişki varlığına yönelik hareket edebilmesi, bunun yanı sıra suçluluk utanç gibi negatif duygularla sağlıklı bir şekilde baş etmesi somatik şikayetlerde ve sağlığa yönelik kaygılarda yordayıc1 görünmektedir. Yoğun suçluluk ve utanç gibi depresogenik duyguların ve kaygının ağır bastığı yakın ilişkilerin bireyin stresle baş etme becerilerini etkilediği öngörülmektedir. Bağlanma tarihçesi olumsuz duyguları 
içeren ve suçluluk yahut utancın baskın olduğu öz değerler taşıyan birey, bu süreçler sonucunda adeta bedenini kurban ilan etmektedir. Kaygının, olumsuz yaşantının, zorlayıcı kuralların/yasakların ve tereddüttün hakim olduğu ilişkiler vücutta temsil edilmektedir. Dolayısıyla biyopsikososyal açıdan işlevselliği tehlikeye atan somatizasyonu sürdüren yapıların anlaşılması önem arz etmektedir. Gerek toplumsal politikaları gerekse psikopatoloji yaygınlığını önlemeye ilişkin koruyucu programları yapılandırılırken ilgili bulguların süreç açısından işlevsel bilgiler sağladığı düşünülmektedir. Ayrıca cinsiyetler arası farklılıklar göz önüne alındığında, sosyal politikaların ve kültürel tutumların bu farklılığı bertaraf eden uygulamalarının koruyucu olabileceği öngörülmektedir. Bunun yanı sıra ebeveyn eğitim programlarında ya da okullarda verilen rehberlik hizmetlerinde erken dönemdeki bağlanma, suçluluk ve utanç gibi kavramların ele alınmasının önemli olduğu düşünülmektedir. Ayrıca somatik belirtilerin yüksek olduğu popülasyonlarla çalışılırken ilgili değişkenlerin incelenmesinin, yorumlanmasının terapötik müdahale ve psikososyal iyilik hali açısından önemli katkılar sağlayacağ düşünülmektedir.

\section{Kaynakça}

Ainsworth, M.S. (1979). Infant-mother attachment. Am Psychol, 34, 932-937.

Akbağ, M., \& İmamoğlu, S. E. (2010). The prediction of gender and attachment styles on shame, guilt and loneliness. ESTP, 10, 669-682.

Aragona, M., Monteduro, M.D., Colosimo, F., Maisano, B., \& Geraci, S. (2008). Effect of gender and marital status on somatization symptoms of immigrants from various ethnic groups attending a primary care service. Ger J Psychiatry, 11, 63-72.

Ausubel, D.P. (1955). Relationships between shame and guilt in the socializing process. Psychol Rev, 62, 378390.

Barry, J., Seager, M., \& Brown, B. (2015). Gender differences in the association between attachment style and adulthood relationship satisfaction. New Male Studies, 4, 63-74.

Barsky, A.J., Orav, E.J., \& Bates, D.W. (2005). Somatization increases medical utilization and costs independent of psychiatric and medical comorbidity. Arch Gen Psychiatry, 62, 903-910.

Bartholomew, K., \& Horowitz, L.M. (1991). Attachment styles among young adults: A test of a four- category model. J Pers Soc Psychol, 61, 226-244.

Bowlby, J. (1969). Attachment and Loss: Vol.1. Attachment. New York: Basic Books.

Ciechanowski, P.S., Walker, E.A., Katon, W.J., \& Russo, J.E. (2002). Attachment theory: A model for health care utilization and somatization. Psychosom Med, 64, 660-667.

Cirhinlioğlu, F.G., \& Güvenç, G. (2011). Utanç eğilimi, suçluluk eğilimi ve psikopatoloji. IJHS, 8, 248-267.
Dağ, I. (1991). Reliability and validity of the Turkish form of the SCL90-R. Türk Psikiyatri Derg, 2, 5-12.

Derogatis, L.R. (1977). SCL-90: Administration, Scoring and Procedure Manual-I for the Revised Version. Baltimore, MD: John Hopkins Univ. School of Medicine, Clinical Psychometrics Unit.

Derogatis, L.R., Rickels, K., \& Rock, A.F. (1976). The SCL90 and the MMPI: A step in the validation of a new self-report scale. $\mathrm{Br} J$ Psychiatry, 128, 280-289.

Dickerson, S.S., Kemeny, M.E., Aziz, N., Kim, K.H., Fahey, J.L. (2004). Immunological effects of induced shame and guilt. Psychosom Med, 66, 124-131.

Doyle, D.J., Ruskin, K.J., \& Engel, T.P. (1996). The internet and medicine; Past, Present and The future. Yale $J$ Biol Med, 69, 429-37.

Eastin, M.S., \& Guinsler, N.M. (2006). Worried and wired: effects of health anxiety on information-seeking and health care utilization behaviors. Cyberpsychol Behav, 9, 494-498.

Ford, C.V. (1986). The somatizing disorders. Psychosomatics, 27, 335-337.

Griffin, D. W., \& Bartholomew, K. (1994). Models of the self and other: Fundamental dimensions underlying measures of adult attachment. Journal of Personality and Social Psychology, 67(3), 430-445.

Harder, D.W., Cutler, L., Rockart, L. (1992). Assessment of shame and guilt and their relationship to psychopathology. J Pers Assess, 59, 584-604.

Harvey, O.J., Gore, E.J., Frank, H., \& Batres, A.R. (1997). Relationship of shame and guilt to gender and parenting practices. Pers Individ Dif, 23, 135-146.

Karaırmak, Ö., \& Güloğlu, B. (2014). Deprem Deneyimi Yaşamış Yetişkinlerde Bağlanma Modeline Göre Psikolojik Sağlamlığın Açıklanması. C.U. Faculty of Education Journal, 43, 1-18.

Kılıç, M. (1991). Belirti tarama listesinin (SCL-90-R) geçerlilik ve güvenilirliği. Türk PDR Dergisi, 1, 4552 .

Kidd, T., \& Sheffield, D. (2005). Attachment style and symptom reporting: Examining the mediating effects of anger and social support. Br J Health Psychol, 10, 531-541.

Kirmayer, L., \& Robbins, J. (1991). Three forms of somatization in primary care: prevalence, cooccurrence, and sociodemographic characteristics. J Nerv Ment Dis, 179, 647-65.

Lesser, L.M., Ford, C.V., \& Friedmann, C.T.H. (1979). Alexithymia in somatizing patients. Gen Hosp Psychiatry, 1, 256-261.

Lewis, H. B. (1971). Shame and Guilt in Neurosis. New York: International Universities Press.

Li, N., He, J., \& Li, T. (2009). Gender difference of insecure attachment: Universal or culture-specific? Behavioral and Brain Sciences, 32(1), 36-37. 
Lipowski, Z.J. (1987). Somatization: Medicine’s unsolved problem. Psychosomatics, 28, 294-297.

Lipowski, Z.J. (1988). Somatization: The concept and its clinical application. Am J Psychiatry, 145, 13581368.

Liu, L., Cohen, S., Schulz, M., \& Waldinger, R.J. (2011). Sources of somatization: Exploring the roles of insecurity in relationships and styles of anger experience and expression. Soc Sci Med, 73, 14361443.

Lopez, F.G., Gover, M.R., Leskela, J., Sauer, E.M., Schirmer, L., \& Wyssmann, J. (1997). Attachment styles, shame, guilt, and collaborative problemsolving orientations. Pers Relatsh, 4, 187-199.

Meissner, W.W. (2006). Psychoanalysis and the mind-body relation: psychosomatic perspectives. Bull Menninger Clin, 70, 295-315.

Noyes, R. J., Longley, S.L., Langbehn, D.R., Stuart, S.P., \& Kukoyi, O.A. (2010). Hypochondriacal symptoms associated with a less therapeutic physicianpatient relationship. Psychiatry, 73, 57-69.

Noyes, R.J., Stuart, S.P., Langbehn, D.R., Happel, R.L., Longley, S.L., Muller, B.A., \& Yagla, S.J. (2003). Test of an interpersonal model of hypochondriasis. Psychosom Med, 65, 292-300.

Pineles, S.L., Street, A.E., \& Koenen, K.C. (2006). The differential relationships of shame-proneness and guilt- proneness to psychological and somatization symptoms. J Soc Clin Psychol, 25, 688-704.

Starcevic, V., Berle, D. (2013). Cyberchondria: towards a better understanding of excessive health-related Internet use. Expert Rev Neurother, 13, 205-213.

Stuart, S., \& Noyes, R. (1999). Attachment and Interpersonal Communication in Somatization. Psychosomatics, 40, 34-43.

Sullivan, M., \& Katon, W. (1993). Somatization: the path between distress and somatic symptoms. Am Pain Soc $J, 2,141-149$.

Sümer, N., \& Güngör, D. (1999). Yetişkin bağlanma stili ölçeklerinin Türk örneklemi üzerinde psikometrik değerlendirmesi ve kültürlerarası bir karşılaştırma. Turk J Psychol, 14, 71-106.

Şahin, N.H., \& Şahin, N. (1992). Adolescent guilt, shame, and depression in relation to sociotropy and autonomy. Paper presented at the World Congress of Cognitive Therapy, Toronto, Canada, 17-21.

Tabachnick, B.G., \& Fidell, L.S. (2015). Çok Değişkenli Ístatistik. Baloğlu M. (Çeviri Ed) 6. Bask1, Ankara: Nobel.

Tangney JP. Conceptual and methodological issues in the assessment of shame and guilt. Behav Res Ther 1996; 34: 741-754.

Tangney, J.P., Miller, R.S., Flicker, R., \& Barlow, D.H. (1996). Are shame, guilt, and embarrassment distinct emotions? J Pers Soc Psychol, 70, 1256-1269.

Tangney, J. P., Stuewig, J., \& Mashek, D. J. (2007). Moral emotions and moral behavior. Annu. Rev. Psychol., 58, 345-372.

Tangney, J.P., Wagner, P.E., \& Gramzow, R. (1992). Proneness to shame, proneness to guilt, and psychopathology. J Abnorm Psychol, 101, 469-478.

Vatan, S. (2017). Duygular ve Psikolojik Belirtiler Arasındaki İlişkiler. Curr Approaches Psychiatry, 9, 45-62.

Waldinger, R.J., Schulz, M.S., Barsky, A.J., \& Ahern, D.K. (2006). Mapping the road from childhood trauma to adult somatization: The role of attachment. Psychosom Med, 68, 129-135

White, R.W., \& Horvitz, E. (2009). Cyberchondria: studies of the escalation of medical concerns in web search. ACM Trans Manag Inf Syst, 27, 23

Woien, S.L., Ernst, H.A.H., Patock-Peckham, J.A., \& Nagoshi, C.T. (2003). Validation of the TOSCA to measure shame and guilt. Pers Individ Dif, 35, 31332.

Wool, C.A., \& Barsky, A.J. (1994). Do women somatize more than men? Gender differences in somatization. Psychosomatics, 35, 445-52. 
EK-1: Etik Kurul Onay1

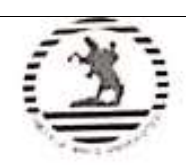

T.C.

ONDOKUZ MAYIS ONIVERSITESI

SOSYAL VE BEŞERI BILIMLER ETIK KURUL KARARLARI

\begin{tabular}{|c|c|c|}
\hline KARAR TARIHI & TOPLANTI SAYISI & KARAR SAYISI \\
\hline 10.09 .2019 & 7 & $2019-268$ \\
\hline
\end{tabular}

KARAR NO: Ôniversitemiz Fen Edebiyat Fakültesi öğretim üyelerinden Doç. Dr. Murat KURT 2019-268 ve Arş. Gör.Gizem GERDAN'ın "Üniversite Öğrencilerinde Somatik Belirtiler, Bağlanma Stilleri ve Suçluluk Utanç Duyguları Arasındaki Iliş̧kinin İncelenmesi" isimli öğretim üyesi araştırmasına ilişkin anket ve psikolojik ölçekler çalıșmasını içeren 30628 sayılı dilekçesi okunarak görüşüldü.

Üniversitemiz Fen Edebiyat Fakültesi öğretim üyelerinden Doç. Dr. Murat KURT ve Arş. Gör.Gizem GERDAN'ın "Öniversite Ögrencilerinde Somatik Belirtiler, Bağlanma Stilleri ve Suçluluk Utanç Duygulan Arasındaki İlişkinin İncelenmesi" isimli ögretim üyesi araştırmasına ilişkin anket ve psikolojik ölçekler çalışmasının kabulüne oy birliḡi ile karar verildi. 